\title{
NON-FINANCIAL SHAREHOLDER ACTIVISM: A PROCESS MODEL FOR INFLUENCING CORPORATE ENVIRONMENTAL AND SOCIAL PERFORMANCE
}

\section{International Journal of Management Reviews}

Final Word version, as accepted 17 July 2017

\author{
Gary Cundill \\ Cranfield School of Management \\ Cranfield, Bedford \\ MK43 OAL \\ Tel: $0044(0) 1234751122$ \\ Email: gary.cundill@cranfield.ac.uk \\ (Corresponding author) \\ Dr Palie Smart \\ Cranfield School of Management \\ Cranfield, Bedford \\ MK43 OAL
}

Tel: 0044 (0)1234 751122

Email: palie.smart@cranfield.ac.uk

Professor Hugh N. Wilson

Cranfield School of Management

Cranfield, Bedford

MK43 OAL

Tel: 0044 (0)1234 751122

Email: $\underline{\text { hugh.wilson@cranfield.ac.uk }}$ 


\title{
NON-FINANCIAL SHAREHOLDER ACTIVISM: A PROCESS MODEL FOR INFLUENCING CORPORATE ENVIRONMENTAL AND SOCIAL PERFORMANCE
}

\begin{abstract}
SUMMARY
Shareholders have become increasingly active in endeavouring to influence companies' environmental and social practices. In comparison with the mature field of financiallymotivated shareholder activism, limited enquiries have been carried out on its non-financial counterparts. This article synthesises the knowledge base through a review of the academic literature, exploring shareholder activism intended to impact corporate environmental and social performance. Theoretical perspectives appropriate to this phenomenon are critically appraised, in particular insights from social movement theory, Hirschman's theory of exit, voice and loyalty and stakeholder salience theory, as well as the roles of signalling and symbolic management actions. Data from the literature are organised into a process model of non-financial shareholder influence. Underpinned by the influencing context, this conceptualisation centres on three primary shareholder interventions: divestment, dialogue and shareholder proposals. These interventions are enabled through a range of actors and tools: coalitions, non-governmental organisations, codes and indices, the media and regulators. The interaction between interventions and the enabling actors and tools helps to determine managers' perceptions of shareholder salience. These perceptions subsequently shape the organisational behaviours that impact companies' symbolic and substantive environmental and social performance. An agenda to direct future research in this burgeoning field is articulated.
\end{abstract}




\section{INTRODUCTION}

Shareholder activism has been studied for more than a century (Gillan and Starks 2007; Rutterford 2012), tracking a trajectory of increasing influence on company managers (McKinsey \& Company 2014). Typically, the purpose of this activism has been to improve a company's financial performance (Martin and Nisar 2007; Schneider and Ryan 2011; Denes et al. 2017), and only comparatively recently have shareholder activists begun to prioritise environmental and social performance (Goranova and Ryan 2014). With the rise in awareness of global sustainability challenges among incoming generations, such priorities are now widely on display in the press (e.g. Flood 2015; McKibben 2015). In the United States (US) the number of shareholder proposals relating to environmental and social issues has risen by half in the past decade, with more than 400 in 2015 (US SIF 2016). The Interfaith Centre on Corporate Responsibility (ICCR) alone filed 67 climate-change related proposals that year (ICCR 2016).

Academic examination of this sub-field of shareholder activism has commenced but is yet to establish a body of evidence comparable to that of financial shareholder activism. By way of illustration, Goranova and Ryan's (2014) review of the academic literature brought together the streams of financial and social shareholder activism. In their table of activism outcomes, only 5 of 38 papers reviewed relate to social or environmental performance. Sjöström's (2008) review of shareholder activism for corporate social responsibility, a construct integrally linked to corporate environmental and social performance (Aguinis and Glavas 2012), identified 34 articles and working papers, most of which were published after 2003. The pace of publication has increased and more than half of the articles that form our article's literature base appeared after Sjöström's review. This burgeoning body of literature points to the need for the assembly and organisation of ideas which are currently partial and fragmented. 
Our review locates, critically appraises and synthesises relevant academic literature that examines shareholders' influence over companies' environmental and social performance. The methodology used to develop the literature base for the review is described in an appendix. In summary, a systematic approach was used to create a foundational set of articles which was then supplemented through interactions with other academics and the wider literature base. Our article is situated in the context of a broad body of literature dealing with company stakeholders, classically described by Freeman as 'any group or individual who can affect or is affected by the achievement of the organisation's objectives' (1984: 46). The subset of stakeholders of primary interest in this review is shareholders, those who have an ownership stake in the organisation, and the activity of these shareholders that will be examined is that of non-financial activism, the influencing of company environmental and social performance by using this ownership stake (Sjöström 2008).

Most research has been carried out in the US and to a lesser extent the United Kingdom (UK). The reasons for this may include the well-established tradition of shareholder activism in the US (Rutterford 2012), the existence of the US ICCR's large database on social shareholder activism (Clark et al. 2008), and the availability of detailed analysis on US companies' social and environmental performance from, inter alia, KLD Research and Analytics and the US government's Toxic Release Inventory (Fisher-Vanden and Thorburn 2011).

We now analyse the main theoretical approaches used in the expanding sub-field of nonfinancial shareholder activism. We then provide a process model to show how shareholders may influence company management and how they may increase managers' perceptions of their salience to achieve their aims. These shareholder interventions and their enablers are evaluated in light of the main theoretical approaches. Finally, an agenda for further research based on the process model is offered prior to concluding remarks. 


\section{THEORETICAL APPROACHES TO NON-FINANCIAL SHAREHOLDER}

\section{ACTIVISM}

We have identified a range of theoretical approaches in the academic literature that deals with shareholder activism relating to company environmental and social performance. Exemplar references from this literature are provided in Table 1 . What follows is an analysis of some of the most prominent and potentially useful theories that will in subsequent sections be brought to bear on a process model for this form of shareholder activism.

Table 1: Primary theoretical approaches within the shareholder activism literature

\begin{tabular}{l|l}
\hline \multicolumn{1}{c|}{ Theoretical perspective } & \multicolumn{1}{c}{ Exemplar references } \\
\hline Agency theory & $\begin{array}{l}\text { Jensen and Meckling (1976); Fama (1980); Fama and Jensen } \\
\text { (1983); Eisenhardt (1989). }\end{array}$ \\
\hline Stakeholder theory & $\begin{array}{l}\text { Freeman (1984); Donaldson and Preston (1995); Phillips } \text { et al. } \\
\text { (2003); Hasnas (2013). }\end{array}$ \\
\hline Institutional theory & $\begin{array}{l}\text { DiMaggio and Powell (1983); Suddaby (2010); Greenwood et al. } \\
\text { (2014); Meyer and Höllerer (2014). }\end{array}$ \\
\hline $\begin{array}{l}\text { Social movement theory } \\
\text { Exit, voice and loyalty }\end{array}$ & $\begin{array}{l}\text { Tilly (1978); McAdam (1982); Davis and Thompson (1994). } \\
\text { and Oc (2015). }\end{array}$ \\
\hline Signalling & Spence (1974); Connelly et al. (2010); Taj (2016). \\
Stakeholder salience theory & Mitchell et al (1997); Neville et al. (2011). \\
\hline
\end{tabular}

\section{Understanding relationships: principals, stakeholders, institutions and social movements}

Agency theory would seem eminently suitable for explaining shareholder-management interaction because of its intuitive and legally based view that shareholders, as principals of the company, delegate authority to managers as their agents so that the latter may perform the service of managing the company (Jensen and Meckling 1976). This is indeed the primary framework deployed by scholars in the case of financial shareholder activism (Davis and Thompson 1994; Goranova and Ryan 2014). Yet it is less suitable to describe what is usually a minority group of shareholders (Logsdon and Van Buren 2009) attempting to exert influence over managers with respect to corporate environmental and social performance. In 
such a situation, a simplistic application of agency theory results in the problems of determining the principal's expectations and even exactly who the principal might be. Corporate financial performance over a period frequently serves as a proxy for the principal's desires when financial shareholder activism is being considered (Boerner 2006). However, the interests of non-financial shareholder activists may diverge from those of other shareholders.

The process of identifying the principal when the shareholder body is heterogeneous warrants examination in the light of stakeholder theory, which recognises that managers have to make decisions in light of a range of disparate and almost certainly conflicting interests (Parmar et al. 2010). Developed as it has been to cater for a set of actors ranging from employees to governments to trade associations, stakeholder theory can cope with a potentially heterogeneous shareholder base (Donaldson and Preston 1995). This descriptive capability is useful to map shareholder entities and their demands pertaining to corporate environmental and social performance (Lee 2008; Henisz et al. 2014). However, it falls short of being able to explain exactly how these shareholders' influencing attempts may impact on the company itself (Frynas and Stephens 2015).

What is needed is an understanding of how managers react to attempts by shareholders to influence aspects of company environmental and social performance. Institutional theory can be deployed usefully to describe intra-organisational processes (Bengtsson 2007; Luo et al. 2012). It can be applied beyond a single organisation to explain phenomena at the level of the organisational field (Greenwood et al. 2014), which could prove helpful in describing the effects of non-financial shareholder activism on a particular industry or sector of business. It has been argued, however, that the theory's primary purpose is to understand how and why organisations react to certain aspects of their environment and not to others (Suddaby 2010). 
When a company's environment includes a shareholder attempting to exert influence over its environmental or social performance, institutional theory suggests managers may take their cue from established norms (Daudigeos 2013); for example, by publishing a sustainability report. In an uncertain environment, organisations may adopt a mimetic strategy (DiMaggio and Powell 1983), modelling their response to activists on that of their peers with isomorphic results. Institutional theory also explains how coercion is an influencing mechanism that may work when others don't (Kostova et al. 2008): a shareholder dissatisfied with, say, a company's polluting activities may engage with government agencies to encourage enforcement of regulations.

Institutional theory therefore seems to have important insights to offer when examining non-financial shareholder activism. In the company, it can explain the impact of managers' actions on corporate environmental and social performance through an evaluation of how and why the actions of individuals take place (Suddaby 2015). Extending the analysis to the context in which companies operate, it may explain how non-financial shareholder influence is affected by such institutional conditions as regulation and the presence of nongovernmental organisations (NGOs) (Campbell 2007).

Agency theory's description of relationships with the company as a nexus of contracts (Fama 1980) fails to capture the range of actors that may be involved in non-financial shareholder activism-activism that may be described as comprising a social movement (Goranova and Ryan 2014). Social movement theory argues that such a movement is likely to form when the interests of actors are shared, are few and are readily recognised (Tilly 1978) — a situation readily obtainable when shareholders are seeking to influence social and environmental company behaviour. A sense of shared identity and social ties help to develop social infrastructure, such as the ICCR, which allows mobilisation towards a specific objective as the activists begin to acquire control of required resources (Davis and Thompson 
1994). Such mobilisation may be enhanced during periods of instability, such as protest action against globalisation, which render the status quo susceptible to influence (McAdam 1982). We turn now to consider the influencing act itself.

\section{Forms of influence: exit, voice and loyalty}

Shareholder attempts to exert influence on company environmental or social practices are often described in terms of Hirschman's (1970) concept of voice. In Hirschman's conception, voice is a political action, aimed at changing an undesirable state of affairs while remaining invested in the company (Bahshur and Oc 2015). In the case of non-financial shareholder activism, action may take the form of dialogue with company managers, or shareholder proposals at a general meeting (Clark and Hebb 2005).

Because most researchers adopt definitions of shareholder activism that exclude any fundamental change in the relationship between the shareholder and the company (Gillan and Starks 1998), divestment is usually excluded from the discussion (Rho 2006). By defining all shareholder activism as forms of voice, Hirschman's second action, exit, is neglected, thereby reducing the theory's explanatory power. In contrast to Goranova and Ryan (2014) we have included screening and divestment in our analysis, grouping them together in the process model we describe later. Screening based on social or environmental criteria is fundamental to most socially responsible investment approaches (Richardson and Cragg 2010) and it would seem unwise to exclude this. Similarly, there have been times such as during the campaigns against South African apartheid when divestment was a widely publicised form of shareholder activism (Beaty and Harari 1987). These activities also may be described in terms of the use of an ownership stake to exert influence.

It would seem important to be able to explain why a shareholder may choose between the options of voice and exit. Hirschman (1970) attempted to do so by introducing a third construct, namely loyalty. Different from exit and voice in that it is not an action, loyalty can 
be regarded as a moderator of these actions (Saunders 1992), its presence usually making exit less likely and voice more so (Hirschman 1970). While Barry (1974) is unnecessarily unkind in describing loyalty as 'an ad hoc equation filler', its usefulness is reduced because it is not the only determinant of the choice between exit and voice. Hirschman himself (1980) later noted that both voice and exit may be suppressed by external circumstances, regardless of loyalty. As we shall note later, these circumstances include the regulatory environment as well as the environmental or social issue of concern to the shareholder.

\section{Forms of response: signals and symbols}

To influence corporate environmental and social performance, shareholders will attempt to convey information to managers (Lewis and Mackenzie 2000; Haigh and Hazelton 2004; David et al. 2007), a form of signalling (Spence 1974). To achieve the shareholder's aims this signalling needs to be observable by management (Connelly et al. 2010), and the anticipated outcomes of signalling may be adversely affected by unintended negative signalling (Taj 2016). Managers in turn may send signals to shareholders, either in response to shareholder action or to pre-empt it (Goranova et al. 2007; Miller and Triana 2009; Zhang and Wiersema 2009; Robinson et al. 2011).

Having signalled to managers a desire for a change in company performance, it is reasonable for a shareholder to expect a response. Often the desired response would entail changes to company operations that are substantive - actual and concrete changes (Ashforth and Gibbs 1990). Managers may not wish to make these changes, however, and may therefore engage in symbolic actions that appear to conform to shareholders' desires, but do not actually result in changes to organisational activities (Rodrigue et al. 2013). These symbolic actions are decoupled from actual practices (Meyer and Rowan 1977), but provide a legitimising explanation of company actions (Zajac and Westphal 1995). Managers may in this way lead shareholders to believe that their demands have been met, thereby relieving any 
pressure being brought to bear upon them (Westphal and Zajac 1998). Such symbolic management may impact deleteriously on the effectiveness of shareholder influence, as we will note later.

\section{Acquiring managers' attention: stakeholder salience}

Managers typically have many demands upon their time, and work in a world replete with conflicting signals. They are constantly having to answer, at least by their actions, Freeman's question as to 'who and what really counts' (1994: 411), a question of identification: which stakeholders and which issues should they take into consideration? Shareholders seeking to exert influence naturally want managers to perceive them as salient. Mitchell et al. (1997) studied stakeholder identification and salience by considering stakeholder attributes. Defining salience as 'the degree to which managers give priority to competing stakeholder claims' (p. 854), they proposed that a stakeholder's salience may be determined by evaluating its attributes of power, legitimacy and urgency. Power is a stakeholder's ability to get another entity to do something it otherwise would not have done; legitimacy is the perception that a stakeholder's actions are desirable or appropriate; and urgency is the extent to which a stakeholder's claims call for immediate attention (Mitchell et al. 1997). Gifford (2010) found the theory to be useful when applied to the shareholder subset of stakeholders, and we shall use its insights repeatedly in later discussion of our process model as we describe managerial perceptions and actions when under pressure from shareholders.

It is surprising that this potentially useful theory has seen limited development (Neville et al. 2011). While salience has typically been understood in terms of perceptions (Mitchell et al. 2011), Eesley and Lenox (2006) redefined it in terms of actions. This may prove to be a useful modification, allowing for greater empirical assessment of the construct, not least when attempting to determine the effectiveness of shareholders' attempts to influence 
company performance. Neville et al. (2011) distinguished carefully between the stakeholder and the stakeholder's claim, resulting in a more nuanced definition of stakeholder salience: 'the prioritisation of stakeholder claims by managers based on their perception of the degree of power of the stakeholder and the degree of moral legitimacy and urgency of the claim' ( $\mathrm{p}$. 369). They went on to show that managerial response is thus determined, at least in part, by managers' identification and then prioritisation of the stakeholder itself, as well as by their identification and prioritisation of the claim the stakeholder is making on the organisation. Perrault and Clark (2016) found that stakeholder status and reputation affected managerial response, suggesting that Mitchell et al.'s (1997) model may be usefully extended to incorporate other elements.

Having laid a foundation of theoretical perspectives on shareholder-manager interaction, we now discuss a process model that describes how shareholders may influence company environmental and social performance.

\section{A PROCESS MODEL FOR NON-FINANCIAL SHAREHOLDER INFLUENCE}

We chose the term 'influence' as it may be used to describe the interactions between shareholders and companies without unduly limiting the nature of these interactions. This terminology is in line with that used recently by Goranova and Ryan (2014) and McNulty and Nordberg (2016). We define influence as the altering of what would otherwise have been the course of events in the absence of an influencing intervention (Coughlan et al. 2001). In the context of shareholder-company interaction, such influence would not normally extend to the point where shareholders assume managerial duties: to do so would be to take on the very roles of the agents who are appointed to manage the company (Fama and Jensen 1983). Current codes of corporate conduct would not support shareholders taking on such a role, both because shareholders don't have fiduciary duties to the company (Institute of Directors 
of Southern Africa 2016), and because of the impracticality of attempting to manage a company by means of shareholder referendums (OECD 2015).

\section{The context of influence}

Figure 1 outlines a process model for shareholder influence on company environmental and social performance. It starts with the context in which this influencing takes place, as this has an impact on the influencing act and its outcomes. Current research distinguishes between institutional and smaller shareholders (Clark and Hebb 2005), not forgetting agency issues between investors and fund managers (Hirst in press), and the discussion that follows will show how different categories of shareholders may choose different approaches to exert influence. This is particularly pertinent to non-financial shareholder activism by actors as disparate as a giant pension fund such as CalPERS (Barber 2007) and an individual gadfly (Mathews 2015). Shareholders' motivations may differ: for example, a union's interest in employee working conditions (McCabe 2000), a pension fund's consideration of the impact of a company's activities on its other investments (Kiernan 2007), and an investor's desire to reduce non-financial risk (Ho 2016).

Figure 1: A process model for shareholder influence

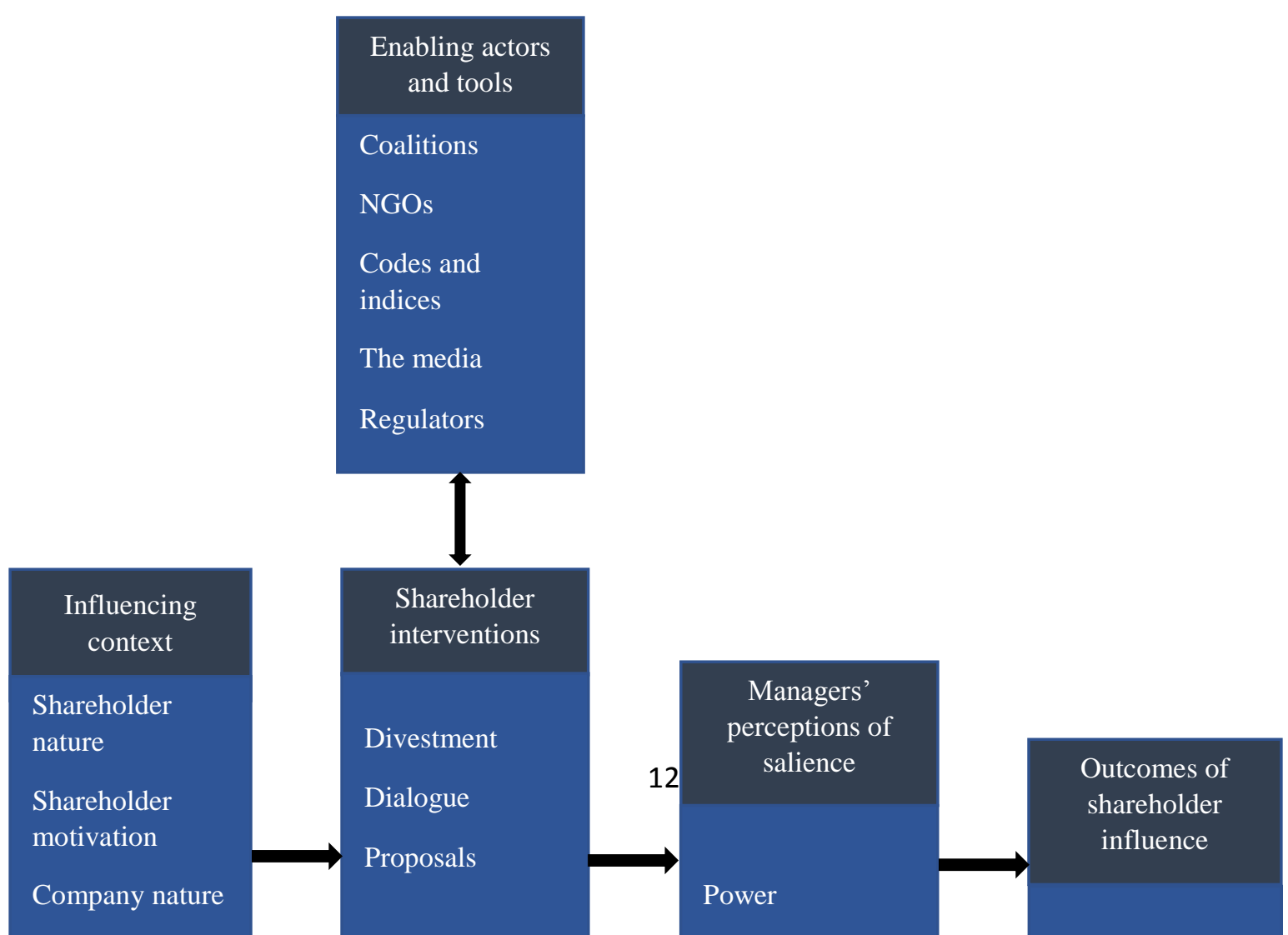


Company characteristics and the sector in which a company operates have also been shown to impact shareholder actions (Judge et al. 2007). Adopting a social movement perspective, Rehbein et al. (2004) find evidence that company size is a determinant of whether shareholders may target it, and whether its environmental performance is of concern, or whether it is in an industry known to have a poor employment or community interaction record. Activists may elect to work in a cooperative manner with progressive companies, while candidly challenging companies adopting a policy of resistance (den Hond and de Bakker 2007). However, as will be described in greater detail in the discussion on the outcomes of shareholder influence, a company that sends accommodating signals to a shareholder may merely be engaging in a symbolic management exercise (Marcus and Goodman 1991).

Changes in the regulatory environment over the years have been shown to impact significantly on shareholder activism (Rutterford 2012) and on its effects (Kock and Min 2016). The means of this impact may range from facilitating shareholder proposals to encouraging socially responsible investment (Yamahaki and Frynas 2016). Lastly, to provoke shareholders to act there must be an environmental or social issue, or combination of issues, that matters sufficiently to shareholders for them to commence their activism (Judge et al. 2007). The nature of the issue may determine the activist's approach: an investor may, for example, see ethical screening as the only legitimate intervention in a particular industry (Van Duuren et al. 2016). It may also alter managerial perceptions of shareholder saliency: a 
scandal recently unearthed could provide the support of urgency to the shareholder's attempt at influence (Löscher 2012).

\section{Interventions}

A close reading of the literature reveals three fundamental influencing interventions available to shareholders: divestment of shares, dialogue with management, and shareholder proposals at general meetings. Linked to these interventions, the literature describes a set of enablers that may increase managers' perceptions of the salience of the shareholder. We will now analyse these interventions and associated enablers, evaluating them in the light of the main theoretical perspectives described earlier.

Divestment. Shareholders dissatisfied with a company's environmental or social performance may choose to sell all or part of their shareholding in that company-classically described as Hirschman's (1970) option of exit (Nooteboom 1999). The application of this influencing approach extends beyond simple divestment, as the same principle may lead to a shareholder not investing in a company, business sector or geography in the first place (Eccles and Viviers 2011) — a strategy of avoidance (Sparkes and Cowton 2004) commonly referred to as ethical screening (Collison et al. 2009). The flip-side of this screening approach, albeit less common, is best-of-breed investing (Hood et al. 2014) - investing only in companies that have particularly progressive environmental and social practices. This may be seen as extending Hirschman's options of exit and voice to an antecedent action: entrance- a term only used in the literature more recently (Glac 2010).

Divestment is not always practical. It presupposes the context of a reasonably liquid equity market to keep the cost of exit low, not the case for all companies or all markets (Wen 2009). Neither is it an option for passive investors bound to follow a specific index (Gifford 2010), the index here serving to enforce loyalty to its constituents. Furthermore, large investors may be unable to sell their holdings without substantially damaging share prices and their own 
returns (Rao and Sivakumar 1999), again raising the exit cost. These are examples of why shareholders may exhibit apparent loyalty to a company, despite concerns over its environmental or social performance (McNulty and Nordberg 2016).

Also, the effectiveness of the divestment intervention may be questioned. In the absence of any other engagement process, divestment or screening fails to send a clear signal to managers as to what aspects of a company's environmental or social performance a shareholder is unhappy with (Eccles 2010). By divesting from (or not investing in) the company, investors forfeit the ability to exercise their voices as shareholders. A better way to wield the divestment stick, therefore, may be to signal to managers by threatening to sell, rather than by selling immediately (Gifford 2010; Crifo and Forget 2013). However, if the threat of divestment is to be perceived as salient by management, the consequent divestment or screening process must carry real, negative implications for the company. We turn to this now.

Managers' perceptions of the salience of divestment and screening activities may be seen in terms of the power that these actions have to affect the company's cost of capital (Haigh and Hazelton 2004; Lewis and Mackenzie 2000). To have a measurable effect on the share price, however, a significant proportion of the investor community must refuse to hold the share in question, and this is not usually the case (Johnsen 2003). At the height of the antiapartheid divestment campaign, the IRRC concluded that 'divestment will in all probability never have a direct economic effect on any South Africa-related company' (Beaty and Harari 1987: 38). Fossil fuel divestment and restriction policies are perhaps the equivalent course of action today, but in 2014 accounted for only \$42.9 billion in money manager and institutional investment assets - barely $0.1 \%$ of the $\$ 36.8$ trillion assets under professional management in the US (US SIF 2015). It is apparent, therefore, that managers need not worry overmuch about their companies' cost of capital being materially affected by ethical investors who rely 
on screening and divestment approaches, unless these investors become far more prevalent. Given this lack of power, shareholders contemplating the use of this intervention to influence managers may need to consider increasing managers' perceptions of the legitimacy and urgency of their demands by involving one or more of the enablers that we will describe later.

Dialogue. Shareholders may exercise their voices (Hirschman 1970) by engaging in dialogue with a company's management with a view to influencing the company's environmental and social performance. While such dialogue is usually conducted in private (Logsdon and Van Buren 2009), the shareholder may write articles, issue press briefings, address conferences or become involved in industry initiatives (Lewis and Mackenzie 2000), thereby adding an element of urgency to the discussions. Public confrontation, however, is generally regarded as fundamentally different to dialogue (Logsdon and Van Buren 2009), and may harm managers' perceptions of the legitimacy of the shareholder's demands.

Dialogue may be used as a stand-alone intervention. This is frequently the case with large institutional shareholders who find it comparatively easy to gain access to a company's management because managers recognise their power and legitimacy (Gifford 2010). Furthermore, such shareholders usually do not wish their activism to become public knowledge, lest the company in which they have invested be damaged (Wen 2009). These shareholders may be too large to easily exit their investment and, therefore, they are likely to seek to exercise influence via their voice (Hirschman 1970). More usually, dialogue is part of a broader process of interaction and is typically a precursor to a shareholder resolution (Haigh and Hazelton 2004; Sparkes and Cowton 2004).

There are times, however, when dialogue only occurs once a resolution has already been submitted (O'Rourke 2003). In this case the urgency associated with the shareholder resolution process may have raised managers' perceptions of the salience of the shareholder's demand and they may then elect to enter into dialogue with the shareholder. There are other 
factors that may cause a company to agree to engage privately with shareholders. By keeping the engagement behind closed doors, potentially reputation-damaging issues can be kept from the media, and political actors such as regulators can be kept ignorant of problematic environmental and social corporate performance (Rehbein et al. 2013). Secrecy makes it difficult for powerful and legitimate shareholder/stakeholder coalitions to form around shared interests, thus reducing the possibility of social mobilisation and allowing the company more flexibility to shape the dialogue's agenda (Rehbein et al. 2013).

Given the time and resources expended by both shareholders and managers in the process, it would seem important for both parties to determine how effective dialogue is for influencing companies' environmental and social performance. The evidence in the academic literature on this is both incomplete and inconclusive. Dialogue may result in the shareholder obtaining preferential access to information not readily available in the public domain (Clark and Hebb 2005; Logsdon and Van Buren 2009), which may be the shareholder's desired outcome. By its nature dialogue is likely to result in managers reaching a better understanding of the expectations of shareholders, potentially causing them to alter company practices accordingly (Logsdon and Van Buren 2009). While these outcomes reduce information asymmetry between the parties by enabling the two-way signalling process, they don't necessarily constitute a substantive impact by shareholders on environmental and social performance. However, the process may enable shareholders to signal clearly to managers what their expectations are, allowing managers to understand shareholders' motivations. As Van Cranenburgh et al. (2013) show in a broader stakeholder context, this may help managers formulate responses that are practical for the company and address at least in part shareholders' concerns. It may, however, also enable them to merely craft a more plausible symbolic response instead of encouraging a substantive change in corporate performance (Westphal and Zajac 1998). 
There are indications that companies may acquiesce to shareholder requests simply because they do not have the time or resources for lengthy dialogue (Rehbein et al. 2013). Such acquiescence may, however, be merely a symbolic management exercise by managers (Westphal and Zajac 1994). Reviewing research into one institutional investor's ongoing dialogue with companies on social issues, Wen (2009) notes that managers responded to the investor's concerns in more than 95\% of cases. Sparkes and Cowton (2004) are less sanguine in their assessment of the effectiveness of dialogue, finding that NGOs campaigning in the public arena view private dialogue as futile. Lewis and Mackenzie (2000) observe that much dialogue in the UK is limited to investors requesting clarity on company policy and informing the company of the investors' own ethics policies-symbolic actions not likely to influence environmental and social performance significantly.

What is evident from the literature is that the effectiveness of dialogue is difficult to research, not least because of the lack of public artefacts (Logsdon and Van Buren 2009; Wen 2009). When the content of discussions that take place in secret is unknown, and when even the fact that such discussions have taken place may not be disclosed, it is practically impossible to draw lines of correlation, let alone causation, between shareholder-manager dialogue and a change in a company's environmental or social performance (Mallow and Sethi 2016). It is doubtless because it is difficult to research this approach to influencing that most of the empirical literature describing shareholder activism concentrates on shareholder proposals, for which information is readily available. This is despite the reported increasing popularity of the use of dialogue (Rehbein et al. 2013) and despite the widely held view that dialogue is more powerful than public activism (Goranova and Ryan 2014).

Examples certainly exist of investors claiming that their entering into dialogue with a company resulted in changes to that company's actions. Two cases in point are USS's interactions with Balfour Beatty and with GlaxoSmithKline (Clark and Hebb 2005). 
However, in neither case did the companies acknowledge that shareholder influence played any part in changing its actions. A detailed study of Goldcorp's interaction with a shareholder coalition does show a changed approach, but whether that change was substantive is questioned by the researcher himself (Dhir 2012).

In summary, except for the role that dialogue may play in the shareholder proposal process, or the threat of a shareholder making use of this process (Lewis and Mackenzie 2000), there is no unequivocal evidence in the reviewed literature that shows that shareholder dialogue impacts on managers' actions with respect to environmental or social issues. This implies that shareholders are not in a position to determine the extent to which they should deploy their resources in this area as opposed to choosing an alternative approach to influencing, nor can they determine how they may best increase managers' perceptions of their salience in the dialogue process.

Shareholder proposals. There is another way in which shareholders may choose to make their voices heard, rather than exiting their investment (Hirschman 1970). In many jurisdictions, shareholders have a right to present proposals at a company's Annual General Meeting (AGM) and invite other shareholders or their proxies to vote on them (Gillan and Starks 2007).

In the past, most proposals relating to environmental and social issues were filed by small shareholders and faith-based groups for whom financial return was not the sole determinant of their investment strategy. Their numbers have now been swelled by share-owning NGOs and unions (Matsusaka et al. 2016), as well as an increasing number of institutional investors for whom divestment is an unattractive option (BlackRock 2016). Because this particular process of shareholder-management interaction is arguably the focus of environmental and social shareholder activism (Lydenberg 2007), it is well worth examining its outcomes. The norm is for shareholder resolutions on social and environmental issues to fail to be passed by 
vote (Haigh and Hazelton 2004), as it is seldom the case that interest in such resolutions is widely held. Even when this hurdle is crossed, the resolution is only precatory (Dhir 2012) and thus not binding, although companies are increasingly likely to implement resolutions that do achieve a majority vote (Goranova and Ryan 2014). This is probably a result of the perceived legitimacy of a significant proportion of shareholders expressing their views in this way.

The shareholder proposal process, sometimes referred to as the proxy process (Amao and Amaeshi 2008), does, however, allow shareholders to exert influence. It is a formal way for shareholders to signal their discontent with a company's policies and practices (David et al. 2007), thereby bringing an issue to the attention of management. The effort required to prepare and submit such proposals may also increase managers' perceptions of the salience of these shareholders, their perceived legitimacy being increased by their demonstrably taking the matter seriously (Gifford 2010).

Being a public process, it exposes aspects of a company's policies and practices to a variety of stakeholders (David et al. 2007). If these stakeholders have similar interests, this may provide an opportunity to develop a social infrastructure to mobilise more broadly to pressure the company. This, in turn, may lead to managers seeing the shareholder as more powerful and imparting a sense of urgency to their responses. A tabled proposal may lead to negative publicity and a level of embarrassment for company managers (Clark et al. 2008). Proposals may be a useful public education tool (Emel 2002) and may influence political processes involving regulators and others, using existing social infrastructure for mobilisation purposes. A perceived increase in urgency may then lead to management engaging in dialogue with the shareholder concerned (Dhir 2012), an outcome which is possibly the shareholder's main objective (O'Rourke 2003). 
The literature on substantive outcomes of the proposal process is ambiguous (Clark et al. 2008). Dhir (2012) remarks that shareholder proposals may translate into future company policy, although this may be decoupled from company practice. A limited range of case-study research has provided some evidence of shareholder resolutions leading to improvements in companies' social and environmental performance (e.g. Emel (2002) on Freeport-McMoran). It appears more common, however, for shareholder activism to be reported without clear indications of its effects (e.g. Sjöström (2010) on Cisco, Google and Yahoo!). The IRRC's database notes shareholder resolutions that were withdrawn before voting as an indicator that some form of compromise between the shareholder and management was reached. However, no convincing data exist showing whether companies made any substantive changes desired by the shareholder after the proposal was withdrawn (O’Rourke 2003).

More frequent in the literature are observations that such interventions are largely unsuccessful (Haigh and Hazelton 2004), leading at best to marginal changes in company practices. It would be an unusual manager who would willingly give up executive power to a shareholder, so a shareholder proposal may lead to the unintended consequence of managers acting to safeguard their discretionary powers (David et al. 2007). David et al.'s (2007) research establishes a negative relationship between proposals and corporate social performance, a finding explainable in terms of symbolic managerial action (Westphal and Zajac 1998). Fisher-Vanden and Thorburn (2011) established that climate-related shareholder resolutions led to companies joining the Climate Leaders and Carbon Disclosure Project (CDP) voluntary initiatives-symbolic actions.

Nevertheless, there is evidence that resolutions become more effective in changing practice if the company or its peers have previously been targeted in this way (Reid and Toffel 2009). Proffitt and Spicer (2006) attribute this path-dependent effect to the impact of an increase in perceived legitimacy of the shareholder by the company's management. 
O'Rourke (2003) suggests that the shareholder proposal process may be effective, but only as part of a larger campaign. As noted earlier, mobilisation around the issue of interest will be facilitated by the building of social infrastructure, particularly in a context of political opportunity (Davis and Thompson 1994).

Not all shareholders see the process as useful, with some viewing it as a blunt and often ineffective instrument (Clark and Hebb 2005). The very specificity of many environmental and social proposals may count against their gaining support from a majority of shareholders (Towner 2014). This is borne out by social movement theory's emphasis on the importance of issues needing to be both shared and readily recognised (Davis and Thompson 1994).

\section{Enabling actors and tools}

We turn now to a set of actors and tools that may serve as enablers, enhancing (or perhaps detracting from) the perceived salience of shareholders seeking to exert influence through the three interventions analysed above. The interactions between the enablers and the shareholder interventions take place in a multiplicity of ways. Shareholders may form coalitions, collectively mobilising to introduce proposals to advance their interests. NGOs may take up shareholdings to exercise influence. Other shareholders may create investment codes to promote environmental responsibility and solicit the support of the media and regulators to further their aims.

Coalitions. Interaction between a shareholder and a company need not be one-on-one nor need it be direct; there is a range of other possibilities. A high proportion of attempts by shareholders to influence companies on environmental or social matters arise from shareholder coalitions. One of the best-known is the ICCR (Dion 2009), founded in 1971. Numerous other shareholder-led coalitions exist, ranging from those such as the Council of 
Institutional Investors (Lewis and Mackenzie 2000) which were set up to promote shareholder influence in general, to organisations such as the Shareholder Action Network (Haigh 2006) that focus on social and environmental issues.

The roles that these organisations play varies considerably, but there are some functions that most of them fulfil to some extent at least. They follow developments in their area of interest, identify relevant issues for action, disseminate information relating to these issues, and propose strategies and tactics for action (Neubaum and Zahra 2006). They also serve as a rallying point for individual shareholders seeking to influence companies (Clark et al. 2008). Shareholder activism can be costly, and these organisations facilitate cost-sharing with other shareholders (Neubaum and Zahra 2006). These activities are readily described in terms of social movement theory, as they bring together shareholders who share similar interests and often focus on just one or a few of these interests. They provide a social infrastructure by facilitating ties between shareholders and afford them a shared identity - that of being members of a like-minded crowd. Lastly, they promote mobilisation by pooling and controlling coalition member resources.

There is broad agreement in the academic literature on the factors that may make such coalitions influential. Tighter coalition coordination increases shareholder salience in the eyes of managers (Neubaum and Zahra 2006). The involvement of large and hence apparently powerful institutional investors is generally regarded as important (Sparkes and Cowton 2004), their status increasing the salience of other shareholders (Perrault and Clark 2016). Clear framing by coalitions of the sometimes disparate voices of an array of shareholders makes it easier for managers to understand shareholders' expectations (Neubaum and Zahra 2006), ensuring the clarity of signals that are sent.

Nevertheless, as already noted, evidence of the ability of these coalitions to effect changes in companies' environmental or social performance is not overwhelming. One likely reason is 
that, as indicated earlier, managers are unlikely to attribute their actions on environmental or social performance to shareholder pressure. What coalitions do provide, however, is an opportunity for individual shareholders to increase managers' perceptions of their salience by helping to create the conditions of a social movement, bringing together actors with shared interests and pooling resources to facilitate mobilisation.

Non-governmental organisations. A stakeholder that has become increasingly influential (Guay et al. 2004) is the NGO wishing to make its voice heard. Some NGOs, such as the CDP, establish codes of practice or reporting (Luo et al. 2012) that may be used as tools by shareholders. These will be considered in the section immediately following this one. NGOs include religious, environmental, labour and other interest groups (Logsdon and Van Buren 2009). They may elect to purchase a shareholding specifically to exert influence over a company's environmental or social performance, perhaps hoping that better organisational knowledge may strengthen their arguments (Briscoe and Gupta 2016). Some such as ShareAction (ShareAction 2016) provide shareholders with tools and encouragement to exercise their voice on corporate environmental and social performance. NGOs such as Fossil Free Stanford (Fossil Free Stanford 2015) encourage shareholders to divest themselves of companies of whose performance they disapprove. Rather like shareholder coalitions, they may contribute towards the shareholder activism movement by mobilising shareholders with specific interests, providing the social infrastructure for the group to thrive in. However, their activities are not normally restricted to purely shareholder-based actions and tend to include other influencing interventions such as boycotts, demonstrations and media campaigns (Emel 2002).

The actual effect of NGOs' activities on companies' performance is uncertain, however (Guay et al. 2004; Marshall et al. 2007). Emel (2002) found that companies were prepared to be influenced by NGOs only in non-core areas of their operations, such as the provision of 
social services. Managers may elect to address NGO pressure in symbolic ways by arranging site visits, preparing reports and supplying press releases (Kolk 1999), thereby signalling their apparent responsiveness and potentially defusing conflict with shareholders and other stakeholders (Nartey et al. 2013) while not changing the company's substantive performance.

Indices and codes. This category of enablers comprises tools rather than actors that shareholders may use to increase managers' perceptions of their salience. Some examples are sustainability indices such as the Dow Jones Sustainability Index (DJSI), the FTSE4Good, and the FTSE/JSE Johannesburg Stock Exchange's Socially Responsible Investment Index (JSE SRI) (Collison et al. 2009; Hamann et al. 2009; Robinson et al. 2011), the last-named having recently become the FTSE/JSE Responsible Investment Index. Others are sets of principles such as the United Nations Global Compact's Principles for Responsible Investment (Post 2013), and still others are reporting standards and platforms such as the CDP. The sources of such indices and codes may range from NGOs to professional bodies to companies (Kolk et al. 1999), or to combinations of a variety of stakeholders (Fransen and Kolk 2007). (Government actors will be discussed below, but it is worth noting that some of these initiatives can be classified as a form of civil regulation (Kolk et al. 2008).)

Shareholders may use these tools in a variety of ways. They may demand that companies comply with industry codes. They may divest from companies that are not part of a sustainability index. They may make use of information from company reports prepared in accordance with such codes to take decisions about who and how to target with their influencing interventions. They may pressure managers to demonstrate the quality of their disclosures by employing external assurance providers (Perego and Kolk 2012).

There are those who hold the view that standards such as these exercise substantive influence, and that companies and whole industries will change their behaviour if their performance is observed, measured and reported (Reid and Toffel 2009; Slager et al. 2012). 
Empirical evidence offers little support for this belief. Cho et al. (2012) even found that company environmental performance is negatively related to membership of the DJSI, another example of symbolic management activities.

Part of the reason for this may be that such indices and codes can be used by managers to either pre-empt or respond to shareholder pressure. Once a company has appeared on an index or is shown to have implemented a code, the salience of shareholder demands may diminish as a result of the company having enhanced its own legitimacy. This reduces, at least relatively, the legitimacy of shareholder demands. Cho et al. (2012) note that inclusion in the DJSI relates more to the symbolic action of disclosure than actual performance, and that the DJSI thus appears to be reducing companies' incentives to improve their performance. In their assessment of the FTSE4Good, Collison et al. (2009) found nothing to contradict these results, noting that engagement with companies at risk of being excluded from the index does result in the criteria of the index being met. These criteria, however, focus on policies and disclosure rather than substantive performance. In the South African context, Hamann et al. (2009) found no statistically significant evidence of membership of what was then the JSE SRI being linked to corporate social performance, with the sole exception of Black Economic Empowerment indicators.

Media. The media may be described as an enabling actor, providing shareholders with a means to exercise and strengthen their voice (Flew 2009). The media are certainly able to increase the salience of other actors, mainly by exercising normative power (Gifford 2010), often through threatening an executive's reputation and public standing (Neubaum and Zahra 2006). Jia et al. (2016) found that in the context of environmental performance the more negative and more local the media coverage, the greater the impact on corporate performance. The media may also be used by shareholders who are threatening to divest or who are attempting to solicit support for a proposal scheduled to be voted on at an AGM 
(O'Rourke 2003), enhancing the volume and potentially the clarity of the signal they wish to send to the company's management. The effects of a shareholder's involvement of the media in a matter of environmental or social performance may also extend beyond the target company. Similar companies may perceive such action as a threat that they may be next in line or may be adversely affected by dint of their operating in the same sector (Waldron et al. 2013) - a mimetic force acting at the level of the institutional field.

However, as noted earlier, use of the media may also detract from a shareholder's perceived legitimacy and undermine whatever relationship may exist with the company (Gifford 2010). A compromise approach is to use the media to raise awareness of particular issues rather than to publicly confront a company (Gifford 2010), thereby permitting mobilisation on an issue without directly targeting an individual company. While media campaigns are often referred to in the literature as a useful tool for exerting influence (Oh $e t$ al. 2013), there is little clear evidence of their stand-alone effectiveness when it comes to changing a company's environmental or social impacts. The media are also available to companies, who may use them to weaken a shareholder's influencing attempts (Kolk, 1999; Henisz 2014), possibly detracting from company performance in the process (Calveras and Ganuza 2016). Returning to the foundations of social movement theory, it may be best for shareholders to view media use critically, focusing on where this can publicise shareholder interests (Davis and Thompson 1994) and, perhaps more controversially, destabilise the political status quo (McAdam 1982).

Regulators. The regulating environment is described in our process model as a contextual factor, an antecedent to shareholder influence (Kolk and Levy 2001). It was, after all, a change in regulation that allowed social and environmental shareholder proposals to be first filed in the US in 1970 (Goranova and Ryan 2014). That change in regulation was achieved by an activist in the District of Columbia Court of Appeals (Medical Committee for Human 
Rights v. SEC). Such action falls within Hirschman's (1970) construct of voice, as he describes the situation where an appeal is made through another entity which enjoys some measure of influence over the company. It would be incorrect, however, to limit the role of regulators to the context in which shareholder influence is exerted, as they can fulfil a directly interventionist role too. It is noteworthy that other forms of shareholder influence rely largely on management's cooperation to be effective. Regulators are not limited in this way (O'Rourke 2003) and, therefore, may enable shareholders to increase dramatically their salience in terms of power and urgency.

Regulators may enhance shareholder salience in several ways. Shareholders may threaten to lobby regulators when managers prove resistant to their demands, and there is evidence that, in accordance with social movement theory's predictions, shareholder activism is more effective when companies or sectors are under the threat of regulation (Reid and Toffel 2009). Regulators may make use of information from shareholder activists to develop appropriate legislation and enforcement regimes (David et al. 2007; Rehbein et al. 2013). Regulators may even facilitate activism by supporting shareholder initiatives (Gifford 2010). Lastly, there are externalities that can only be addressed effectively by regulators (Haigh and Hazelton 2004), and in these cases it makes sense for shareholders to involve the authorities accordingly.

Managers faced with concerted action by shareholders and regulators may react in a variety of ways. They may, of course, simply comply with what government asks of them (Ward et al. 2009). Historically, however, they have engaged in corporate political activity to oppose regulatory action (Kolk and Pinkse 2005; Hadani et al. 2016). In a similar manner to that described above, they may form coalitions to increase government's perceptions of their own salience (Kolk and Pinkse 2007). They may also promote the adoption of voluntary 
environmental and social programmes to deflect onerous regulatory instruments (Lyon and Maxwell 2007).

\section{Managers' perceptions of shareholder salience}

Managers are not noted for a desire to give up their autonomy to parties external to the company (Gelter 2009). Therefore, for a shareholder to exert influence over managerial decision-making to effect a change in corporate environmental or social performance, managers will need to perceive the shareholder as salient (Waldron et al. 2013). As noted earlier, Mitchell et al. (1997) have suggested that this salience may be expressed in terms of stakeholder power, legitimacy and urgency, with other attributes such as status and reputation also playing a role (Perrault and Clark 2016).

The influencing context has a role to play in establishing the perceived salience of a shareholder. A shareholder may enjoy greater power and legitimacy if its shareholding is relatively large (Clark and Hebb 2005), or if it has a reputation for directing adverse media attention to corporate targets (Waldron et al. 2013), salience here being increased by threat. A sympathetic regulatory environment may affect a shareholder's perceived power (Kock and Min 2016), and the nature of the environmental or social issues under consideration are likely to affect managerial perceptions of the influencing attempt, particularly if peer companies have already been targeted (Judge et al. 2007; Waldron et al. 2013). The nature of the claim the shareholder has on the company will also impact on managerial perceptions, particularly its moral legitimacy (Neville et al. 2011; Dhir 2012).

We have also seen that shareholder salience may be perceived not just in terms of the identity and characteristics of the shareholder (Mitchell et al. 1997), but in terms of the action taken by the shareholder (Eesley and Lenox 2006). The threat of divestment provides a shareholder with power and urgency only to the extent that its shareholding is both significant and unlikely to be taken up by another investor at a price comparable to that already ruling 
(Beaty and Harari 1987). Similar constraints apply in reverse to an investor that has screened a company out of its potential investment universe, with probably even less perceived legitimacy because it currently has no shareholding in the company (Johnsen 2003). Dialogue exercised alone may enhance managers' perceptions of the shareholder's legitimacy, but offers little in the way of power and urgency (Rehbein et al. 2013). Shareholder proposals make use of a legitimate regulatory approach to influence, but their power is restricted by the need to gather wide-spread support, as well as by managers' knowledge that the vote is usually non-binding (Dhir 2012).

Managers will tend to see coalitions of shareholders as having greater power, legitimacy and status than individual shareholders (Neubaum and Zahra 2006; Perrault and Clark 2016), and an NGO may offer a similar boost to a shareholder seeking to exercise influence (Emel 2002). Codes and indices may provide legitimacy to shareholders seeking changes in corporate performance (Kolk et al. 2008), potentially adding mimetic pressure if they are adopted by a company's peers (Perego and Kolk 2012). The media can raise both the power and urgency of a shareholder's efforts (Gifford 2010), while regulators, whose legitimacy depends on the legitimacy of the ruling government itself, can similarly enhance managerial perceptions of power and urgency (O’Rourke 2003).

\section{Outcomes: symbolic and substantive}

The outcomes sought by shareholders seeking to influence corporate social and environmental performance are as heterogeneous as the shareholder base and the range of environmental and social issues of potential interest. A shareholder may wish only to receive a briefing from managers on the company's social policies (Clark and Hebb 2005) or may demand that an oil company ceases drilling in ecologically sensitive areas (King 2014). This diversity in shareholder expectations means that overall remarks about the outcomes of non- 
financial shareholder activism risk being either misleadingly superficial or unhelpfully casespecific. However, some summary observations may be made with a degree of confidence.

When used alone, divestment or screening interventions offer managers limited information and, therefore, have minimal impact on their decision-making with respect to environmental or social company practices (Eccles 2010). While the dialogue process facilitates clear signalling from shareholders as well as managers, its confidential nature prevents us from drawing firm conclusions as to its effectiveness (Logsdon and Van Buren 2009). Shareholder proposals, which provide information to managers and may be readily observed, have been shown to result in changes to company policy, but have had little demonstrable impact on substantive company practice (Dhir 2012) — an example of symbolic management action.

Coalitions can enhance the salience of shareholders engaging in any of these three interventions (Neubaum and Zahra 2006), as can NGOs, but the resultant outcomes remain constrained. However, in certain circumstances NGOs may be satisfied by a symbolic response from companies such as increased disclosure (Marshall and Brown 2007). Shareholders who pressure companies to implement codes and indices may in fact encourage managers to act symbolically to the detriment of substantive corporate environmental and social performance (Cho et al. 2012). Involving the media may well strengthen shareholders' influence over managers, but is also likely to cause managers to deploy at least some company resources to fight back in the media (Henisz 2014; Calveras and Ganuza 2016). Cooperating with regulators, while subject to resistance from managers (Hadani et al. 2016), may offer the most realistic opportunity to drive substantive change in company performance.

We move now from describing the process model to outlining a future research agenda for shareholder influence over corporate environmental and social performance. We note weaknesses in the existing research, explain some barriers to research that have probably 
contributed to these weaknesses, and suggest directions for future research, using our process model as an organising framework.

\section{TOWARDS A RESEARCH AGENDA}

A selection of research opportunities is summarised in Table 2, structured in line with the process model of Figure 1. Commencing with the context, the heterogeneity of the shareholding universe encourages research into whether different types of shareholders approach influencing differently. As we noted in our Introduction, little is known about nonfinancial shareholder activism in the developing world, despite the serious social and environmental impacts of business in these geographies. Also, academic research is limited almost exclusively to listed companies, with little consideration of other ownership models such as private equity partnerships. 


\section{Table 2: Future research opportunities}

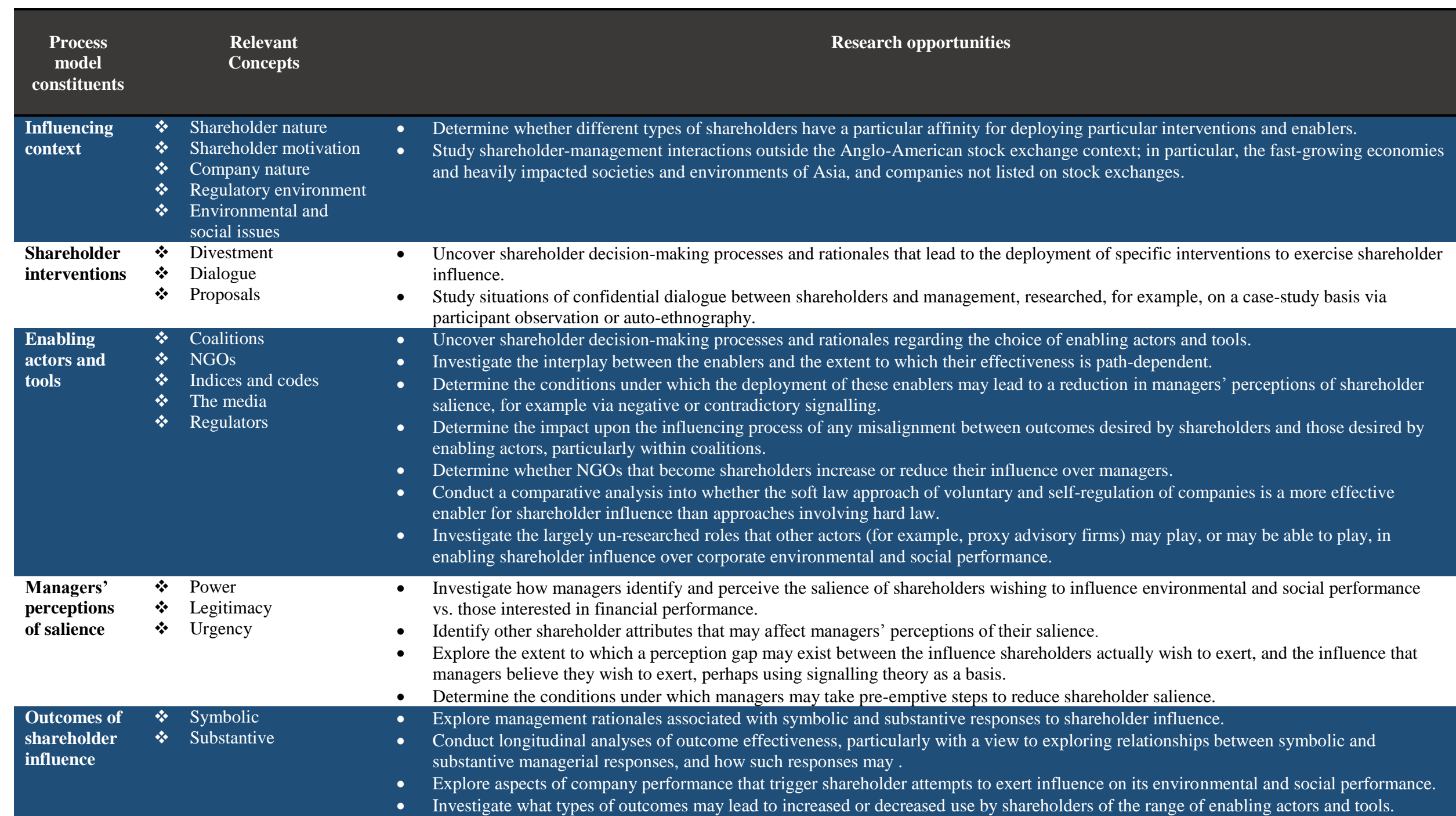


The decision-making processes that a shareholder may go through to decide on which interventions to deploy, and in what sequence, do not appear to have been investigated with any degree of rigour. It would be natural to extend such an investigation into a shareholder's involvement of enablers too. At the level of individual influencing interventions, the divestment and proposals interventions are by their nature comparatively transparent. Little is known, however, of the inner workings of the dialogue process between shareholders and companies.

The deployment for purposes of non-financial shareholder activism of each of the enabling actors and tools described in the process model provides fertile ground for future research. The interplay between them, the possible negative effects that some of them may have on managerial perceptions of shareholder salience, and the impact of differing agendas among the actors are all important issues, but currently under-researched. The degree to which taking up a shareholding increases the influence of an NGO is far from clear, as is the degree to which voluntary regulation of company environmental and social performance can replace a hard law approach. Furthermore, there are other actors such as proxy advisory firms that have the potential to play a significant but currently un-researched role in the influencing process-perhaps a missed opportunity for environmental and social activists to increase their salience with managers.

As more research focuses on financial than non-financial activism, there is insufficient recognition that the use of the needle of influence by a single shareholding activist has a different quality to the wielding of a club by a hedge fund (Gantchev 2013; Goranova and Ryan 2014). Little is known about how managers identify and perceive the salience of shareholders that engage in specifically non-financial shareholder activism, and the range of shareholder attributes that may influence these perceptions. In addition, the decision-making processes followed by managers subject to such activism remain largely opaque to academic 
enquiry. It is likely that significant gaps exist between the messages that shareholders attempt to send to managers, and how these managers perceive these influencing attempts. The cause and nature of these perception gaps should reward further study. Further, the conditions under which managers may take pre-emptive steps to reduce shareholder salience have not been studied.

Lastly, there are significant weaknesses in the academic literature regarding the outcomes of social and environmental shareholder activism. Much of the empirical work focuses on symbolic outcomes such as the adoption of a new code of conduct (Lydenberg 2013). Little evidence is available to indicate substantive changes in corporate environmental and social performance, and less still that credibly links such changes to the interventions of shareholders. The perspectives of signalling and symbolism (or decoupling) should prove useful in such investigations. Company performance outcomes may also result in feedback loops, whether these be the original trigger for shareholder influencing, or the choice by shareholders of specific enablers to enhance their influence, both topics that would bear further investigation.

Not surprisingly, most of the weaknesses identified above are linked closely to the barriers characteristic of research into this domain. At least part of the reason that less research has been carried out into such activism in developing economies and on companies not publicly listed is that useable information is less readily available. Another barrier to understanding this phenomenon is the potentially long-term nature of the influencing process and the likely path-dependence of the effectiveness of the influencing interventions and enablers. Longitudinal studies typically require more and patient resources than, say, a historical event study approach.

The inherent confidentiality and anonymity associated with certain aspects of the processes may constitute the greatest barrier to research (Goranova et al. 2017). Detecting 
what takes place during private dialogue between shareholders and managers, uncovering managers' perceptions of shareholder salience, and discerning what takes place in company offices in response to shareholder influence, present serious challenges to researchers. The last is especially crucial for researchers attempting to discern the extent to which changes in corporate environmental and social performance are related to shareholder influence and which arise from other sources entirely.

Pursuing this research agenda will extend our understanding of the burgeoning field of non-financial shareholder activism. It will allow further development of our process model, explaining influencing processes as yet imperfectly understood. Additional enablers may be found to play important roles in this form of activism, and guidance may be developed for shareholders seeking to influence corporate environmental and social performance, as well as for managers having to respond to such pressures.

\section{CONCLUSION}

This article has synthesised the literature concerned with shareholder influence over company environmental and social performance by means of a process model. The model views shareholder influence as exerted through shareholder interventions enhanced by enabling actors and tools, these choices being shaped by the context of this influence. Managers respond to these interventions depending on the shareholder's perceived saliencewhich again depends on the context-leading to symbolic and/or substantive outcomes. We have evaluated selected theoretical perspectives on the phenomenon of non-financial shareholder activism, noting several limitations of the agency, stakeholder and institutional perspectives. Hirschman's constructs of exit, voice and loyalty provides a useful framework for the options available to shareholder activists, and social movement theory can explain how enablers facilitate the necessary social infrastructure and mobilising conditions for shareholder influence. The insights of stakeholder salience theory allow these interventions 
and enablers to be analysed in terms of its constructs of power, legitimacy and urgency. Furthermore, the role of signalling between shareholders and managers is significant in the influencing process, together with the temptation for managers to engage in symbolic actions to avoid making substantive changes to practice.

The constituents of context, interventions and enablers in our process model enable a rich analysis of antecedents to managers' perceptions of shareholder salience. Our application of signalling theory to the ways in which shareholders attempt to influence managers warns of the dangers inherent to information asymmetry. Our distinction between symbolic and substantive responses by managers exposes attempts to avoid major changes to organisational functioning. We hope our proposed research agenda will prove useful to guide future scholarship in this important and burgeoning field. 


\section{REFERENCES}

Adams, R., Smart, P., and Huff, S.A. (in press). Shades of grey: guidelines for working with the grey literature in systematic literature reviews for management and organizational studies. International Journal of Management Reviews.

Aguinis, H. and Glavas, A. (2012). What we know and don't know about corporate social responsibility: a review and research agenda. Journal of Management, 38, pp. 932-968.

Amao, O. and Amaeshi, K. (2008). Galvanising shareholder activism: a prerequisite for effective corporate governance and accountability in Nigeria. Journal of Business Ethics, 82, pp. 119-130.

Ashforth, B.E. and Gibbs, B.W. (1990). The double-edge of organizational legitimation. Organization Science, 1, pp. 177-194.

Bahshur, M.R. and Oc, B. (2015). When voice matters: a multi-level review of the impact of voice in organisations. Journal of Management, 41, pp. 1530-1554.

Barber, B.M. (2007). Monitoring the monitor: evaluating CalPERS' activism. Journal of Investing, 16, pp. 66-80.

Barry, B. (1974). Review article: 'Exit, voice, and loyalty'. British Journal of Political Science, 4, pp.79-107.

Beaty, D. and Harari, O. (1987). Divestment and disinvestment from South Africa: a reappraisal. California Management Review, 29, pp. 31-50.

Bengtsson, E. (2007). Organisational approaches to corporate governance: an empirical study on shareholder activism. International Journal of Business Governance and Ethics, 3, pp. 238249.

BlackRock (2016). Investment stewardship: America- Q1 2016. Available at: https://www. blackrock.com/corporate/en-tw/literature/fact-sheet/blk-qtrly-commentary-2016-q1amers.pdf (Accessed: 19 July 2016).

Boerner, H. (2006). Tackling short-termism: mighty tasks ahead for investors, corporations and financial analysts. Corporate Finance Review, 11, pp. 35-42.

Briscoe, F. and Gupta, A. (2016). Social activism in and around organizations. The Academy of Management Annals. 10, pp. 671-727.

Calveras, A. and Ganuza, J-J. (2016). The role of public information in corporate social responsibility. Journal of Economics \& Management Strategy, 25, pp. 990-1017.

Campbell, J. (2007). Why would corporations behave in socially responsible ways? An institutional theory of corporate social responsibility. Academy of Management Review, 32, pp. 946-967.

Cho, C.H., Guidry, R.P., Hageman, A.M. and Patten, D.M. (2012). Do actions speak louder than words? An empirical investigation of corporate environmental reputation. Accounting, Organizations and Society, 37, pp. 14-25. 
Clark, G.L. and Hebb, T. (2005). Why should they care? The role of institutional investors in the market for corporate global responsibility. Environment and Planning A, 37, pp. 2015-2032.

Clark, G.L., Salo, J. and Hebb, T. (2008). Social and environmental shareholder activism in the public spotlight: US corporate annual meetings, campaign strategies, and environmental performance, 2001-04. Environment and Planning A, 40, pp. 1370-1390.

Collison, D., Cobb, G., Power, D. and Stevenson, L. (2009). FTSE4Good: exploring its implications for corporate conduct. Accounting, Auditing and Accountability Journal, 22, pp. $35-58$.

Connelly, B.L., Certo, S.T., Ireland, R.D. and Reutzel, C.R. (2010). Signaling Theory: a review and assessment. Journal of Management, 37, pp. 39-67.

Coughlan, A.T., Anderson, E., Stern, L.W. and El-Ansary, A.I. (2001). Marketing Channels, $\left(6^{\text {th }}\right.$ ed.), Upper Saddle River, NJ: Prentice Hall.

Crifo, P. and Forget, V.D. (2013). Think global, invest responsible: why the private equity industry goes green. Journal of Business Ethics, 116, pp. 21-48.

Daudigeos, T. (2013). In their profession's service: How staff professionals exert influence in their organization. Journal of Management Studies, 50, pp. 722-749.

David, P., Bloom, M. and Hillman, A.J. (2007). Investor activism, managerial responsiveness, and corporate social performance. Strategic Management Journal, 28, pp. 91-100.

Davis, G.F. and Thompson, T.A. (1994). A social movement perspective on corporate control. Administrative Science Quarterly, 39, pp. 141-173.

den Hond, F. and de Bakker, F.G.A. (2007). Ideologically motivated activism: how activist groups influence corporate social change activities. Academy of Management Review, 32, pp. 901-924.

Denes, M.R., Karpoff, J.M. and McWilliams, V.B. (2017). Thirty years of shareholder activism: a survey of empirical research. Journal of Corporate Finance, 44, pp. 405-424.

Denyer, D. and Tranfield, D. (2009). Producing a systematic review. In Buchanan, D.A. and Bryman, A. (eds) The Sage Handbook of Organisational Research Methods, London: Sage, pp. 671-689.

Dhir, A. (2012). Shareholder engagement in the embedded business corporation: investment activism, human rights, and TWAIL discourse. Business Ethics Quarterly, 22, pp. 99-118.

DiMaggio, P.J. and Powell, W.W. (1983). The iron cage revisited: institutional isomorphism and collective rationality in organisational fields. American Sociological Review, 48, pp. 147-160.

Dion, M. (2009). Christian mutual funds, codes of ethics and corporate illegalities. International Journal of Social Economics, 36, pp. 916-929.

Donaldson, T. and Preston, L.E. (1995). The stakeholder theory of the corporation: concepts, evidence, and implications. Academy of Management Review, 20, pp. 65-91.

Eccles, N.S. (2010). UN Principles for Responsible Investment signatories and the antiapartheid SRI movement: a thought experiment. Journal of Business Ethics, 95, pp. 415-424. 
Eccles, N.S. and Viviers, S. (2011). The origins and meanings of names describing investment practices that integrate a consideration of ESG issues in the academic literature. Journal of Business Ethics, 104, pp. 389-402.

Eesley, C. and Lenox, M.J. (2006). Firm responses to secondary stakeholder action. Strategic Management Journal, 27, pp. 765-781.

Eisenhardt, K.M. (1989). Agency theory: an assessment and review. Academy of Management Review, 14, pp. 57-74.

Emel, J. (2002). An inquiry into the green disciplining of capital. Environment and Planning A, 34, pp. 827-843.

Fama, E.F. (1980). Agency problems and the theory of the firm. Journal of Political Economy, 88, pp. 288-307.

Fama, E.F. and Jensen, M.C. (1983). Separation of ownership and control. Journal of Law and Economics, 26, pp. 301-325.

Fisher-Vanden, K. and Thorburn, K.S. (2011). Voluntary corporate environmental initiatives and shareholder wealth. Journal of Environmental Economics and Management, 62, pp. 430445 .

Flew, T. (2009). The citizen's voice: Albert Hirschman's Exit, Voice and Loyalty and its contribution to media citizenship debates. Media, Culture and Society, 31, pp. 977-994.

Flood, C. (2015). Fossil fuel divestment action gathers momentum. Financial Times, 4 May 2015.

Fossil Free Stanford (2015). The case for fossil fuel divestment at Stanford. Available at: http://www.fossilfreestanford.org/uploads/2/3/4/0/23400882/thecaseforfossilfueldivestmentat stanforduniversity2015.pdf (Accessed: 23 January 2017).

Fransen, L.W. and Kolk, A. (2007). Global rule-setting for business: A critical analysis of multistakeholder standards. Organization, 14, pp. 667-684.

Freeman, R. E. (1984). Strategic management: A stakeholder approach. Boston, MA: Pitman.

Freeman, R.E. (1994). The politics of stakeholder theory: some future directions. Business Ethics Quarterly, 4, pp. 409-421.

Frynas, J.G. and Stephens, S. (2015). Political corporate social responsibility: reviewing theories and setting new agendas. International Journal of Management Reviews, 17, pp. 483-509.

Gantchev, N. (2013). The costs of shareholder activism: evidence from a sequential decision model. Journal of Financial Economics, 107, pp. 610-631.

Gelter, M. (2009). The dark side of shareholder influence: managerial autonomy and stakeholder orientation in comparative corporate governance. Harvard Law Review, 50, pp. 129-194.

Gifford, E.J.M. (2010). Effective shareholder engagement: the factors that contribute to shareholder salience. Journal of Business Ethics, 92, pp. 79-97.

Gillan, S.L. and Starks, L.T. (1998). A survey of shareholder activism: motivation and empirical evidence. Contemporary Finance Digest, 2, pp. 10-34. 
Gillan, S.L. and Starks, L.T. (2007). The evolution of shareholder activism in the United States. Journal of Applied Corporate Finance, 19, pp. 55-73.

Glac, K. (2010). The influence of shareholders on corporate social responsibility. Available at: http://www.cebcglobal.org/wp-content/uploads/2015/02/Influence_of_Shareholders_on Corporate_Social_Responsibility.pdf (Accessed: 19 July 2016).

Goranova, M., Alessandri, T. M., Brandes, P. and Dharwadkar, R. (2007). Managerial ownership and corporate diversification: a longitudinal view. Strategic Management Journal, 28, pp. 211-225.

Goranova, M. and Ryan, L.V. (2014). Shareholder activism: a multidisciplinary review. Journal of Management, 40, pp. 1230-1268.

Goranova, M., Abouk, R., Nystrom, P.C. and Soofi, E.H. (2017). Corporate governance antecedents to shareholder activism: a zero-inflated process. Strategic Management Journal, 38, pp. 415-435.

Greenwood, R. Hinings, C.R. and Whetten, D. (2014). Rethinking institutions and organizations. Journal of Management Studies, 51, pp. 1206-1220.

Guay, T., Doh, J.P. and Sinclair, G. (2004). Non-governmental organizations, shareholder activism, and socially responsible investments: ethical, strategic, and governance implications. Journal of Business Ethics, 52, pp. 125-139.

Hadani, M., Doh, J.P. and Schneider, M.A. (2016). Corporate political activity and regulatory capture: how some companies blunt the knife of socially oriented investor activism. Journal of Management. 10.1177/0149206316638162

Haigh, M. (2006). Social investment: subjectivism, sublation and the moral elevation of success. Critical Perspectives on Accounting, 17, pp. 989-1005.

Haigh, M. and Hazelton, J. (2004). Financial markets: a tool for social responsibility? Journal of Business Ethics, 52, pp. 59-71.

Hamann, R., Sinha, P., Kapfudzaruwa, F. and Schild, C. (2009). Business and human rights in South Africa: an analysis of antecedents of human rights due diligence. Journal of Business Ethics, 87, pp. 453-473.

Harvey, C., Kelly, A., Morris, H. and Rowlinson, M. (eds.) (2010). Academic Journal Quality Guide ver. 4. London: The Association of Business Schools.

Hasnas, J. (2013). Whither stakeholder theory? A guide for the perplexed revisited. Journal of Business Ethics, 112, pp. 47-57.

Henisz, W. J. (2014). Corporate diplomacy: Building reputations and relationships with external stakeholders. Saltaire: Greenleaf Publishing.

Henisz, W. J., Dorobantu, S. and Nartey, L. J. (2014). Spinning gold: the financial returns to stakeholder engagement. Strategic Management Journal, 35, pp. 1727-1748.

Hirschman, A.O. (1970). Exit, Voice and Loyalty: responses to decline in firms, organizations and states. Cambridge, MA: Harvard University Press. 
Hirschman, A.O. (1980). Exit, Voice, and Loyalty: further reflections and a survey of recent contributions. Milbank Memorial Fund Quarterly, 58, pp. 430-453.

Hirst, S. (in press). Social responsibility resolutions. Journal of Corporation Law.

Ho, V.H. (2016). Risk-related activism: the business case for monitoring non-financial risk. Journal of Corporation Law, 41, pp. 647-705.

Hood, M., Nofsinger, J.R. and Varma, A. (2014). Conservation, discrimination, and salvation: investors' social concerns in the stock market. Journal of Financial Services Research, $\mathbf{4 5}$, pp. 5-37.

ICCR (2016). 2016 proxy resolutions and voting guide. Available at: http://www.iccr.org/ system/files/reportpub_prop_attachments/2016_iccr_proxyresolutionsandvotingguide_2.pdf (Accessed: 3 July 2016).

Institute of Directors of Southern Africa (2016), Draft King IV Report on Corporate Governance for South Africa 2016, Johannesburg: Institute of Directors of Southern Africa.

Jensen, M.C. and Meckling, W.H. (1976). Theory of the firm: managerial behavior, agency costs and ownership structure. Journal of Financial Economics, 3, pp. 305-360.

Jia, M., Tong, L., Viswanath, P.V. and Zhang, Z. (2016). Word power: the impact of negative media coverage on disciplining corporate pollution. Journal of Business Ethics, 138, pp. 437458.

Johnsen, D.B. (2003). Socially responsible investing: a critical appraisal. Journal of Business Ethics, 43, no. 3, pp. 219-222.

Judge, W.Q., Gaur, A. and Muller-Kahle, M.I. (2010). Antecedents of shareholder activism in target firms: evidence from a multi-country study. Corporate Governance: An International Review, 18, pp. 258-273.

Kiernan, M.J. (2007). Universal owners and ESG: leaving money on the table? Corporate Governance: An International Review, 15, pp. 478-485.

King, E. (2014). Shell's Arctic oil plans face shareholder scrutiny. Available at: http://www. climatechangenews.com/2014/02/25/shells-arctic-oil-plans-face-shareholder-scrutiny/ (Accessed: 24 January 2017).

Kock, C.J. and Min, B.S. (2016). Legal origins, corporate governance, and environmental outcomes. Journal of Business Ethics, 138, pp. 507-524.

Kolk, A. (1999). Evaluating corporate environmental reporting. Business Strategy and the Environment, 8, pp. 225-237.

Kolk, A. and Levy, D. (2001). Winds of change: corporate strategy, climate change and multinationals. European Management Journal, 19, pp. 501-509.

Kolk, A., Levy, D. and Pinkse, J. (2008). Corporate responses in an emerging climate regime: The institutionalization and commensuration of carbon disclosure. European Accounting Review, 17, pp. 719-745. 
Kolk, A. and Pinkse, J. (2005). Business responses to climate change: identifying emergent strategies. California Management Review, 47, pp. 6-20.

Kolk, A. and Pinkse, J. (2007). Multinationals' political activities on climate change. Business \& Society, 46, pp. 201-228.

Kolk, A., van Tulder, R. and Welters, C. (1999). International codes of conduct and corporate social responsibility: can transnational corporations regulate themselves? Transnational Corporations, 8, pp. 143-180.

Kostova, T., Roth, K. and Dacin, M.T. (2008). Institutional theory in the study of multinational corporations: a critique and new directions. Academy of Management Review, 33, pp. 9941006.

Lee, M-D.P. (2008). A review of the theories of corporate social responsibility: its evolutionary path and the road ahead. International Journal of Management Reviews, 10, pp. 53-73.

Lewis, A. and Mackenzie, C. (2000). Support for investor activism among U.K. ethical investors. Journal of Business Ethics, 24, pp. 215-222.

Logsdon, J.M. and Van Buren, H.J. (2009). Beyond the proxy vote: dialogues between shareholder activists and corporations. Journal of Business Ethics, 87, pp. 353-365.

Löscher, P. (2012). The CEO of Siemens on using a scandal to drive change. Harvard Business Review, 90, pp. 39-42.

Luo, L., Lan, Y. and Tang, Q. (2012). Corporate incentives to disclose carbon information: evidence from the CDP Global 500 Report. Journal of International Financial Management \& Accounting, 23, pp. 93-120.

Lydenberg, S. (2007). Universal investors and socially responsible investors: a tale of emerging affinities. Corporate Governance: An International Review, 15, pp. 467-477.

Lydenberg, S. (2013). Responsible investors: who they are, what they want. Journal of Applied Corporate Finance, 25, pp. 44-49.

Lyon, T.P. and Maxwell, J.W. (2007). Environmental public voluntary programs reconsidered. Policy Studies Journal, 35, pp. 723-750.

Mallow, M.J. and Sethi, J. (2016). Engagement: the missing middle approach in the BebchukStrine debate. New York University Journal of Law and Business, 12, pp. 385-406.

Marcus, A.A. and Goodman, R.S. (1991). Victims and shareholders: the dilemmas of presenting corporate policy during a crisis. Academy of Management Journal, 34, pp. 281-305.

Marshall, R., Brown, D. and Plumlee, M. (2007). 'Negotiated' transparency? Corporate citizenship engagement and environmental disclosure. Journal of Corporate Citizenship, 28, pp. 43-60.

Martin, R. and Nisar, T. M. (2007). Activist investment: institutional investor monitoring of portfolio companies. Management Decision, 45, pp. 827-840.

Mathews, C. (2015). 'Rising energy costs, outages threaten Arcelor Mittal', Business Day, 28 May 2015. 
Matsusaka, J.G., Ozbas, O. and Yi, I. (2016). Opportunistic proposals by union shareholders. Available at SSRN: http://papers.ssrn.com/sol3/Papers.cfm?abstract id=2666064 (Accessed: 19 July 2016).

McAdam, D. (1982). Political process and the development of black insurgency 1930-1970, Chicago IL: University of Chicago Press.

McCabe, D.M. (2000). Global labor and worksite standards: a strategic ethical analysis of shareholder employee relations resolutions. Journal of Business Ethics, 23, pp. 101-110.

McKibben, B. (2015). 'Climate fight won't wait for Paris: vive la résistance', The Guardian, 9 March 2015.

McKinsey \& Company (2014). Dealing with activist investors: a conversation with Larry Kanarek. Available at: http://www.mckinsey.com/insights/corporate_finance/dealing with_activist_investors_a_conversation_with_larry_kanarek (Accessed: 16 May 2015).

McNulty, T. and Nordberg, D. (2016). Ownership, activism and engagement: institutional investors as active owners. Corporate Governance: An International Review, 24, pp. 346358.

Medical Committee for Human Rights v. SEC, 432 F.2d 659 (D.C. 1970).

Meyer, R.E. and Höllerer, M. A. (2014). Does institutional theory need redirecting? Journal of Management Studies, 51, pp. 1221-1233.

Meyer, J.W. and Rowan, B. (1977). Institutional organizations: formal structure as myth and ceremony. American Journal of Sociology, 83, pp. 340-363.

Miller, T. and Triana, M. D. C. (2009). Demographic diversity in the boardroom: mediators of the board diversity-firm performance relationship. Journal of Management Studies, 46, pp. 755-786.

Mitchell, R.K., Agle, B.R. and Wood, D.J. (1997). Toward a theory of stakeholder identification and salience: defining the principle of who and what really counts. Academy of Management Review, 22, pp. 853-886.

Mitchell, R.K., Agle, B.R., Chrisman, J.J. and Spence, L.J. (2011). Toward a theory of stakeholder salience in family firms. Business Ethics Quarterly, 21, pp. 235-255.

Nartey, L., Dorobantu, S., \& Henisz, W. (2013). A participatory approach to stakeholder engagement: defining a hierarchy of strategic action, in Engineering Project Organization Conference, 9-11 July 2013, Devil's Thumb Ranch, Colorado.

Neubaum, D.O. and Zahra, S.A. (2006). Institutional ownership and corporate social performance: the moderating effects of investment horizon, activism, and coordination. Journal of Management, 32, pp. 108-131.

Neville, B.A., Bell, S.J. and Whitwell, G.J. (2011). Stakeholder salience revisited: refining, redefining, and refueling an underdeveloped conceptual tool. Journal of Business Ethics, 102, pp. 357-378. 
Nooteboom, B. (1999). Voice-and exit-based forms of corporate control: Anglo-American, European, and Japanese. Journal of Economic Issues, 33, pp. 845-860.

OECD (2015), G20/OECD Principles of Corporate Governance, Paris: OECD Publishing. Available at: http://dx.doi.org/10.1787/9789264236882-en (Accessed: 21 March 2016).

Oh, C.H., Park, J. and Ghauri, P.N. (2013). Doing right, investing right: socially responsible investing and shareholder activism in the financial sector. Business Horizons, 56, pp. $703-$ 714.

O'Rourke, A. (2003). A new politics of engagement: shareholder activism for corporate social responsibility. Business Strategy and the Environment, 12, pp. 227-239.

Parmar, B.L., Freeman, R.E., Harrison, J.S., Wicks, A.C., Purnell, L. and de Colle, S. (2010). Stakeholder theory: the state of the art. Academy of Management Annals, 4, pp. 403-445.

Perrault, E. and Clark, C. (2016). Environmental shareholder activism: considering status and reputation in firm responsiveness. Organization \& Environment, 29, pp. 194-211.

Perego, P. and Kolk, A. (2012). Multinationals' accountability on sustainability: the evolution of third-party assurance of sustainability reports. Journal of Business Ethics, 110, pp. 173-190.

Phillips, R., Freeman, R.E. and Wicks, A.C. (2003). What stakeholder theory is not. Business Ethics Quarterly, 13, pp. 479-502.

Post, J.E. (2013). The United Nations Global Compact: a CSR milestone. Business \& Society, 52, pp. 53-63.

Proffitt, W. and Spicer, A. (2006). Shaping the shareholder activism agenda: institutional investors and global social issues. Strategic Organization, 4, pp. 165-190.

Rao, H. and Sivakumar, K. (1999). Institutional sources of boundary-spanning structures: the establishment of investor relations departments in the Fortune 500 industrials. Organization Science, 10, pp. 27-42.

Rehbein, K., Waddock, S. and Graves, S.B. (2004). Understanding shareholder activism: which corporations are targeted? Business and Society, 43, pp. 239-267.

Rehbein, K., Logsdon, J.M. and Van Buren, H.J. (2013). Corporate responses to shareholder activists: considering the dialogue alternative. Journal of Business Ethics, 112, pp. 137-154.

Reid, E.M. and Toffel, M.W. (2009). Responding to public and private politics: corporate disclosure of climate change strategies. Strategic Management Journal, 30, pp. 1157-1178.

Rho, H. (2006). On defining shareholder activism: exploring the terrain for research. Corporate Ownership and Control, 4, pp. 304-311.

Richardson, B.J. and Cragg, W. (2010). Being virtuous and prosperous: SRI's conflicting goals. Journal of Business Ethics, 92, pp. 21-39.

Robinson, M., Kleffner, A. and Bertels, S. (2011). Signaling sustainability leadership: empirical evidence of the value of DJSI membership. Journal of Business Ethics, 101, pp. 493-505.

Rodrigue, M., Magnan, M. and Cho, C.H. (2013). Is environmental governance substantive or symbolic? An empirical investigation. Journal of Business Ethics, 114, pp. 107-129. 
Rutterford, J. (2012). The shareholder voice: British and American accents, 1890-1965. Enterprise \& Society, 13, pp. 120-153.

Saunders, D. (1992). Introduction to research on Hirschman's Exit, Voice, and Loyalty model. Employee Responsibilities and Rights Journal, 5, pp. 187-190.

Schneider, M. and Ryan, L.V. (2011). A review of hedge funds and their investor activism: do they help or hurt other equity investors? Journal of Management and Governance, 15, pp. 349-374.

ShareAction (2016). ShareAction: Strategic Framework 2016-2021. Available at: https:// shareaction.org/wp-content/uploads/2016/10/SAStrategyFramework2016-2021.pdf (Accessed: 23 January 2017).

Sjöström, E. (2008). Shareholder activism for corporate social responsibility: what do we know? Sustainable Development, 16, pp. 141-154.

Sjöström, E. (2010). Shareholders as norm entrepreneurs for corporate social responsibility. Journal of Business Ethics, 94, pp. 177-191.

Slager, R., Gond, J. and Moon, J. (2012). Standardization as institutional work: the regulatory power of a responsible investment standard. Organization Studies, 33, pp. 763-790.

Sparkes, R. and Cowton, C.J. (2004). The maturing of socially responsible investment: a review of the developing link with corporate social responsibility. Journal of Business Ethics, 52, pp. 45-57.

Spence, A.M. (1974). Market Signaling: Informational transfer in hiring and related screening processes. Cambridge MA: Harvard University Press.

Suddaby, R. (2010). Challenges for institutional theory. Journal of Management Inquiry, 19, pp. $14-20$.

Taj, S.A. (2016). Application of signaling theory in management research: addressing major gaps in theory. European Management Journal, 34, pp. 338-348.

Tilly, C. (1978). From mobilization to revolution. New York, NY: Random House.

Towner, M. (2014). Norway's summit on responsible investing. Journal of Investment Management, 12, pp. 33-44.

Tranfield, D., Denyer, D. and Smart, P. (2003). Towards a methodology for developing evidence-informed management knowledge by means of systematic review. British Journal of Management, 14, pp. 207-222.

US SIF (2015). Report on US sustainable, responsible and impact investment trends 2014. Available at: http://www.ussif.org/Files/Publications/SIF_Trends_14.F.ES.pdf (Accessed: 17 July 2016).

US SIF (2016). The impact of sustainable and responsible investment. Available at: http://www.ussif.org/files/Publications/USSIF_ImpactofSRI_FINAL.pdf (Accessed: 3 July 2016). 
Van Cranenburgh, K.C., Liket, K. and Roome, N. (2013). Management responses to social activism in an era of corporate responsibility: a case study. Journal of Business Ethics, $\mathbf{1 1 8}$, pp. 497-513.

Van Duuren, E., Plantinga, A. and Scholtens, B. (2016). ESG integration and the investment management process: fundamental investing reinvented. Journal of Business Ethics, 138, pp. $525-533$.

Waldron, T.L., Navis, C. and Fisher, G. (2013). Explaining differences in firms' responses to activism. Academy of Management Review, 38, pp. 397-417.

Ward, A.J., Brown, J.A. and Rodriguez, D. (2009). Governance bundles, firm performance, and the substitutability and complementarity of governance mechanisms. Corporate Governance: An International Review, 17, pp. 646-660.

Wen, S. (2009). Institutional investor activism on socially responsible investment: effects and expectations. Business Ethics: A European Review, 18, pp. 308-333.

Westphal, J.D. and Zajac, E.J. (1994). Substance and symbolism in CEOs' long-term incentive plans. Administrative Science Quarterly, 39, pp. 367-390.

Westphal, J.D. and Zajac, E.J. (1998). The symbolic management of stockholders: corporate governance reforms and shareholder reactions. Administrative Science Quarterly, 43, pp. 127-153.

Yamahaki C. and Frynas, J.G. (2016). Institutional determinants of private shareholder engagement in Brazil and South Africa: the role of regulation. Corporate Governance: An International Review, 24, pp. 509-527.

Zajac, E.J. and Westphal, J.D. (1995). Accounting for the explanations of CEO compensation: substance and symbolism. Administrative Science Quarterly, 40, pp. 283-308.

Zhang, Y. and Wiersema, M. F. (2009). Stock market reaction to CEO certification: the signaling role of CEO background. Strategic Management Journal, 30, pp. 693-710. 


\section{APPENDIX}

\section{REVIEW METHODOLOGY}

A preliminary scoping study of a selection of academic and practitioner literature was carried out by searching a range of databases and websites for articles and reports on the interaction between shareholders and companies with respect to environmental and social issues. This scoping study was used to identify terminology associated with the phenomenon of interest and, in particular, the relevant actors and types of interactions between them.

The scoping study informed the development of search strings for the next stage of the review, which was undertaken following the protocol for systematic review developed by Tranfield et al. (2003) and Denyer and Tranfield (2009). The citation databases searched were Proquest, EBSCO Business Source Complete, Science Direct, Scopus and Web of Science.

This stage was restricted to articles in scholarly peer-reviewed journals. Only articles written in English were included. There was no restriction placed on the year of publication other than those inherent in the operations of the electronic databases searched. Duplicates were removed from our sample, and an initial screening was carried out by reviewing each article's title and removing references obviously unrelated to our study. A second screening was then conducted by reviewing the titles, abstracts and keywords for each of these articles. A third screening of the articles was carried out to determine relevance and quality 'fit'. We were aided by using the Chartered Association of Business Schools' Academic Journal Quality Guide (Harvey et al. 2010) ratings as a proxy for journal quality, excluding any articles from journals that were not listed in the guide.

This set of identified articles from electronic sources was then added to from the academic literature by cross-referencing, advice from expert academic panel members (including a systematic review library technician) and academic research dialogues. Aided by serendipity, 
these all contributed to the generation of our final sample of 127 articles from 58 academic journals, together with two articles from Social Science Research Network, one conference paper and seven books. This foundational body of literature was then analysed and synthesised using an integrative approach. References from the grey literature were included where appropriate in order to supplement, complement and illustrate the academic literature, in line with the guidelines in Adams et al. (in press). 